DOI: https://doi.org/10.15407/techned2019.06.018

\title{
IMPROVING PRINCIPLES OF ELECTRIC ENERGY PULSE TRANSFORMATION INTO HIGH-FREQUENCY MECHANICAL ENERGY USING CAPACITIVE METHOD
}

Journal

Publisher

ISSN

Issue

Pages
Tekhnichna elektrodynamika

Institute of Electrodynamics National Academy of Science of Ukraine 1607-7970 (print), 2218-1903 (online)

No 6, 2019 (November/December)

$18-24$

\section{Authors}

O.N. Petrishchev ${ }^{2 *}$, K.L. Nozdrachova ${ }^{1 * *}$, G.M. Suchkov ${ }^{1 * * *}$, R.P. Mygushchenko ${ }^{1 * \star * *}$, O.Yu. Kropachek

1

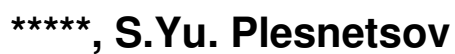

1

1- National Technical University Kharkiv Polytechnic Institute,

2, Kirpichova str., Kharkiv, 61002, Ukraine,

e-mail: hpi.suchkov@gmail.com

2- National Technical University of Ukraine Igor Sikorsky Kyiv Polytechnic Institute,

pr. Peremohy, 37, Kyiv, 03056, Ukraine,

e-mail: petrischev@ukr.net

* ORCID ID : http://orcid.org/0000-0003-2984-1340

** ORCID ID : http://orcid.org/0000-0002-1996-2301

*** ORCID ID : http://orcid.org/0000-0002-1805-0466

**** ORCID ID : http://orcid.org/0000-0002-3287-9772

***** ORCID ID : http://orcid.org/0000-0001-5899-0252

****** ORCID ID : http://orcid.org/0000-0001-8428-5426

\section{Abstract}

Closed solutions of electrostatic and electrodynamics problems are formed in metals for a piecewise-homogeneous medium, where half-space is filled with metal of finite values having electrical conductivity and magnetic permeability being implemented within the framework of a mathematical model for capacitive type sensor when converting electrical energy into 
high-frequency mechanical (ultrasonic). It is shown that a disk transducer of a capacitive type excites forces acting normally on the surface of an electrically conductive product. A quantitative assessment of Coulomb forces for the surface density is carried out. The main factors determining a disk converter sensitivity of capacitive type are stated. Capacitive transducers should be used for measuring, control and diagnostic equipment. References 10, figures 3.

Key words: mathematical modeling, ultrasonic sensor model, capacitive transducers, electric field, charge density, electrode, impulses, measurements, diagnostics.

Received: 19.04 .2019

Accepted: 06.06.2019

Published: 25.10.2019

The work is funded by the authors

\section{References}

1. Ermolov I.N., Lange Yu.V. Nondestructive testing: handbook. Vol. 3: Ultrasonic testing. Moskva: Mashinostroenie, 2004. 864 p. (Rus)

2. Palmer S.B. S. Dixon. Industrially viable non-contact ultrasound. Insight. 2003. Vol. 45. No 3. Pp. 211-217.

DOI: https://doi.org/10.1784/insi.45.3.211.53154

3. Migushchenko R.P., Suchkov G.M., Radev H.K., Petrishchev O.N., Desyatnichenko A.V. Electromagnetic-acoustic transducer for ultrasonic thickness gauging of ferromagnetic metal products without removing the dielectric coating. Tekhnichna Elektrodynamika. 2016. No 2. Pp.78-82. (Rus)

DOI:

https://doi.org/10.15407/techned2016.02.078

4. Suchkov G.M., Alekseev E.A., Zaharenko V.V. Energy and resource-saving devices and technologies of non-destructive testing. Tekhnicheskaia diagnostika i nerazrushaiushchii kontrol. 2006. No 4. Pp. 29-34. (Rus)

5. Zaytseva L.V. Film heterosystems of capacitors based on polyamide, indium oxides, tin and aluminum. PhD thesis: 01.04.07, Institute of electric physics and radiation technologies NAN of Ukraine. Kharkiv. 2015. 190 p. (Ukr)

6. Wright W.M.D., Hutchins D.A. Air-coupled testing of metals using broadband pulses in 
through-transmission. Ultrasonics 37. 1999. No 37. Pp. 19-22. DOI: https://doi.org/10.1016/S0 041-624X(98)00034-1

7. Suchkov G.M., Petrishchev O.N., Nozdracheva E.L., Romanyuk M.I. Excitation of ultrasonic waves in metals by a capacitive transducer. Part 1. Tekhnicheskaia diagnostika $i$

nerazrushaiushchii kontrol.

2015. No 1. Pp.

45-50. (Rus)

8. Tamm I.E. Foundations of electricity theory. Moskva: Nauka, 1976. 616 p. (Rus)

9. Koshlyakov N.S., Gliner E.B., Smirnov M.M. Mathematical physics equations in partial derivatives. Moskva: Vysshaia shkola, 1970. 710 p. (Rus)

10. Feynman R., Leyton R., Sends M. Feynman's lectures on physics. Vol. 5. Elektrichestvo i magnetizm. Moskva: Mir, 1966. 296 p. (Rus)

$\underline{\text { PDF }}$ 